\title{
Mastering the Vocabulary of Meat: A Review Essay
}

\author{
MARK FINLAY
}

Tied to the Great Packing Machine: The Midwest and Meatpacking, by Wilson J. Warren. Iowa City: University of Iowa Press, 2007. xii, 317 pp. Illustrations, graphs, tables, notes, bibliography, index. \$39.95 cloth.

Putting Meat on the American Table: Taste, Technology, Transformation, by Roger Horowitz. Baltimore: Johns Hopkins University Press, 2006. xiii, 170 pp. Illustrations, graphs, notes, index. $\$ 35.00$ cloth, $\$ 19.00$ paper.

THESE DAYS, mastery of a new vocabulary is necessary to understand American meat. Terms such as E.coli 0157:H7, bovine spongiform encephalopathy, LDL cholesterol, halal and kosher butchers, taquería, and others are now commonly associated with American meat, its producers, and its consumers. Such language suggests that issues surrounding American meat production have become increasingly complex and contentious. Meat now has plenty of critics: works such as Jeremy Rifkin's angry Beyond Beef, Eric Schlosser's muckraking Fast Food Nation, Marion Nestle's alarmist Safe Food, and Michael Pollan's sobering In Defense of Food have brought debates about meat processing and its related industries into the national spotlight. Similarly, Deborah Fink's daring and pioneering anthropological study of an Iowa packing plant, Cutting into the Packing Line, deserves special attention for readers of this journal. ${ }^{1}$ In this mi-

1. Jeremy Rifkin, Beyond Beef: The Rise and Fall of the Cattle Culture (New York, 1992); Eric Schlosser, Fast Food Nation: The Dark Side of the All-American Meal (Boston, 2001); Marion Nestle, Safe Food: Bacteria, Biotechnology, and Bioterrorism THE ANNALS OF IOWA 67 (Winter 2008). (C) The State Historical Society of Iowa, 2008. 
lieu, it is fortunate that two fine new books, Roger Horowitz's Meat for the American Table and Wilson Warren's Tied to the Great Packing Machine, provide historical background that helps unpack some of these important and controversial developments.

HOROWITZ'S BOOK offers the broader introduction to the topic. Using Siegfried Giedion's 1947 book, Mechanization Takes Command, as a framework, Horowitz is especially interested in connections between technology and humans' desire to seize control of nature. ${ }^{2}$ Mastery of meat production is no easy prospect, however, since nature ensures that individual animals come in different shapes and sizes, and since physical decay begins from the moment of slaughter. Much of Horowitz's study traces intense efforts to industrialize and standardize animals' bodies so that they correspond with new technologies designed to streamline killing, butchering, packaging, and transportation operations. Although predating Henry Ford by decades, the "disassembly lines" of antebellum Cincinnati (known as "Porkopolis") were an early step in the creation of a highly mechanized industry. Local slaughtering operations disappeared from places such as Manhattan (still the nation's largest beef production center in 1880) and evolved into a highly centralized market epitomized by the Chicago stockyards of Upton Sinclair's The Jungle. ${ }^{3}$ In the twentieth century, technological developments brought continual changes to the butchering and slaughtering trades, so that plants now use hydraulic pressure to separate the last scraps of meat from bone.

Horowitz also focuses on American consumers, seeking to explain how and why they became such enthusiastic consumers of meat. The book offers valuable insights into changes in marketing techniques, showing, for example how new technologies such as refrigeration, self-serve meat counters, and polyvinyl chloride (PVC) wrapping films made it possible for meat to fit

(Berkeley, CA, 2003); Michael Pollan, In Defense of Food: An Eater's Manifesto (New York, 2008); and Deborah Fink, Cutting into the Packing Line: Workers and Change in the Rural Midwest (Chapel Hill, NC, 1988).

2. Siegfried Giedion, Mechanization Takes Command: A Contribution to Anonymous History (Oxford, 1948).

3. Upton Sinclair, The Jungle (New York, 1906). 
cultural standards of modernity. Meats themselves have changed, as we now have fresh pork instead of brine-cured scraps, boneless chicken parts rather than "New York dressed" birds with gizzards and feet attached, and name-brand, mass-produced hot dogs instead of sausages handmade at corner butcher shops.

The chapter on chicken is especially interesting. Once a rare meal, the postwar chicken has been at the center of both a radical change in the nature of the animal and a conceptual shift in the American diet. Horowitz describes "Chicken of Tomorrow" and similar campaigns that brought together supermarket operators, government agricultural promoters, university scientists, and others who helped design an animal that could be bred, fed, slaughtered, and marketed from egg to home meal in just seven weeks. These cases show how Americans have increasingly demanded cheap and convenient meat products, even if it means tolerating hidden issues such as the antibiotics and other additives that go into livestock feeds, ignoring the ethical questions associated with keeping thousands of animals in confined and polluted spaces before killing them, and failing to seek an answer to one common question - what actually goes into a hot $\operatorname{dog}$ ?

WILSON WARREN asks somewhat different questions. Using William Cronon's Nature's Metropolis, as well as works of the economic geographer Brian Page as a framework, Warren is most interested in the relationship between the rural and urban places where meat has been produced, the people who have worked in the processing plants, and the industry's impact on the upper Midwest. ${ }^{4}$ Warren successfully demonstrates that the midwestern packing industry offers insights into the overall destabilization of American industry and labor in the late twentieth and early twenty-first centuries.

Warren divides the history of midwestern meatpacking into four distinct but overlapping phases. First was the "merchant wholesaling" phase, from about 1820 to 1865, when Cincinnati

4. William Cronon, Nature's Metropolis: Chicago and the Great West (New York, 1991). Among Brian Page's works, see "Across the Great Divide: Agriculture and Industrial Geography," Economic Geography 72 (1996), 376-97. 
and other Ohio River towns dominated the trade. It was a seasonal industry, often supplied by individual farmers who drove their own hogs to the slaughterhouses that built links to networks of grocers and merchants.

The "terminal marketing phase," dominant in many places from 1865 to 1950, emerged as new technologies such as refrigerated railcars and sophisticated ice storage systems allowed railroad terminal towns to become centers of slaughtering and packing operations. Challenging an assumption that Chicago's stockyards and its oligarchy of the "Big Four" producers were prototypical for the entire industry, Warren devotes considerable attention to other towns - such as Omaha, Kansas City, Milwaukee, Topeka, Sioux City, and St. Joseph, Missouri-that also were profoundly affected by the daily arrival and slaughter of hundreds of cattle and pigs. Although Warren acknowledges some differences, his findings essentially confirm Upton Sinclair's brutal exposé of a century ago.

Phase three, "early direct marketing," emerged from the 1920s to 1950s, as smaller and independent packers recognized that they could purchase hogs directly from farmers. This system relied on trucks rather than railroads to bring animals to the packing plant. Such animals lost relatively less weight from the stress of transportation and thus required less time on the feedlot before slaughter. This system cut into the Big Four's oligarchy, and allowed for the emergence of a number of smaller packing towns, such as Ottumwa, Cedar Rapids, Dubuque, and Waterloo in Iowa; Madison, Wisconsin; and Austin, Minnesota. This era also produced a relatively favorable climate for union activity, which helped ameliorate the harsh labor conditions of the Chicago stockyards.

The final, "modern direct marketing phase" brought a paradigm shift that has revolutionized midwestern meatpacking. It began in 1961, when two executives at Swift broke away to establish Iowa Beef Packers and a new plant near Denison, Iowa. IBP (now part of Tyson Foods) and its remaining competitors (ConAgra, now part of Swift, and Excel, now part of Cargill) in this new oligopoly have been committed to industrializing the cattle and hog organism so that every specimen is nearly identical. These firms employ new technologies that replace skilled 
butchers and others tradesmen and tradeswomen, and increase line speeds in ways that leave workers at the mercy of the machines. Most significantly, the firms have consolidated cutting and packaging operations so that vacuum-packed and boxed meat can be marketed directly to grocers and food brokers. As a part of these changes, the beef packing industry rapidly moved farther west, closer to the feedlots that hover near small towns such as Garden City, Kansas, where labor unions have no presence. More recently, the pork-producing industry has shifted in similar ways, away from the decentralized and often unionized packing plant operations that once dotted the Iowa landscape to states such as North Carolina that have allowed the modern industry to become a prototype of vertical integration.

A native of Ottumwa, Warren is especially interested in the shift from the third to the fourth phase. His earlier scholarship, which includes several articles published in the Annals of Iowa, establishes that he is an expert on Ottumwa's prominence as a meatpacking town and workers' struggles there to gain union representation. Warren reveals some sympathy for the bygone days when the stench of meatpacking operations represented the "smell of money" (166). Although far from ideal, meatpacking jobs offered an opportunity for many midwesterners to gain a foothold in the middle class. Ottumwa and similar towns became magnets for workers from surrounding rural areas, supported decent manufacturing jobs in ancillary industries, permitted relatively high levels of home ownership, and fostered a sense of community. In contrast, Wilson contends that the fourth phase "benefited neither workers nor the larger communities" (43). Oligarchic firms employ a largely immigrant workforce, one that generally has been unable to win the attention of weakened regulatory agencies, to move from mobile homes into more permanent residences, or to build the strong communities that once characterized the midwestern town. The newer packing towns such as Denison, Iowa; Liberal, Kansas; and Lexington, Nebraska, experience relatively high rates of petty crime, teen pregnancy, and drug abuse. In contrast to the Ottumwa of Wilson's parents' generation, modern meatpacking towns have been shaken by rapid demographic upheavals, overburdened hospitals and schools, and fractured communities. Meanwhile, 
the same shifts brought lasting unemployment, poverty, and depopulation to old packing towns such as Ottumwa.

In the remainder of the book, Warren offers informative but somewhat disjointed chapters that address the role of women in the meatpacking industry, debates over the ethics of animal slaughter, the environmental hazards associated with meat processing, and a brief history of some animal byproducts industries. One traces changing patterns in American meat consumption, although Warren's discussion is not as comprehensive or as engaging as Horowitz's treatment of similar material.

This points to a larger difference between the two books. Already buttressed with 20 pages of appendixes and tables, Warren's text is overloaded with additional data on nearly every imaginable aspect of the industry-local unemployment rates, per capita rates of meat consumption, changes in consumer purchasing power, decennial shifts in local ethnicity, and more. Such data provide plenty of supporting evidence, but at the cost of a strong narrative. Furthermore, the work's organizational structure leads to excessive repetition. For instance, we are told three times (44, 70, and 94) that many workers in Marshalltown, Iowa, immigrated from Villachuato, Mexico; four times in three pages $(157,158$, and 159) that hamburgers claim a fast-growing segment of the American diet; and twice (142 and 160) that Chicken McNuggets were introduced in 1983. In contrast, Horowitz has a lively writing style and delivers his message with a narrative verve. His book is far too brief to fully address any of the topics that it introduces, he allows a few errors to appear in the text, and his index is quite poor, but Putting Meat on the American Table probably will be a standard introduction to this topic for decades to come.

BOTH BOOKS are valuable and somewhat complementary. Horowitz shows why meat is so central to the American experience and why Americans crave meats that are relatively inexpensive, safe, and predictable. Warren, on the other hand, has more to say about the costs of these developments, particularly on the communities of the rural Midwest. Horowitz explicitly avoids any condemnation of meat producers and suggests that consumer behavior rather than corporate greed has shaped 
many of the unsavory developments. In contrast, Warren is more blunt in condemning the current situation and challenges readers to employ "diligent public pressure" (98) and "consumer pressure to change workplace conditions" (138). Although neither book scolds those who choose to eat meat, both encourage readers-meat-eaters and non-meat-eaters alike - to learn the vocabulary associated with modern meat, and to think more carefully about the historical, economic, cultural, social, and cultural circumstances that have made the United States a meateating nation.

Wilson J. Warren won the 2008 Benjamin F. Shambaugh Award for Tied to the Great Packing Machine: The Midwest and Meatpacking. With this award, the State Historical Society of Iowa recognizes the most significant book on Iowa history published each year. 